\title{
Pengaruh Minat Baca Siswa Terhadap Hasil Belajar Pada Pelajaran Bahasa Indonesia di SD Negeri 1 Ciporang
}

\author{
Mia Zultrianti Sari ${ }^{1}$, Agus Gunawan ${ }^{2}$, Yani Fitriyani ${ }^{3}$, Nurul Hilaliyah ${ }^{4}$ \\ 1,2,4Universitas Kuningan, ${ }^{3}$ Universitas Pendidikan Indonesia \\ mia.zultrianti.sari@uniku.ac.id
}

\section{Sejarah Artikel}

diterima 14 Juli 2020 disetujui 20 November 2020 diterbitkan 1 Desember 2020

\begin{abstract}
The purpose of this study is to determine the effect of reading interest on student learning outcomes. This study uses a quantitative approach with survey methods. The population in this study were all high class students, amounting to 197 students. The data collection used was a Likert scale questionnaire. The data analysis technique used simple regression analysis. The results showed that there was a positive and significant effect of reading interest on the learning outcomes of Indonesian high-grade students at SDN 1 Ciporang, Kuningan Regency. The results of data processing show that students 'reading interest according to respondents' perceptions reaches $43,66 \%$ including the high criterion category and student learning outcomes reaching 62,95\% including the low criteria category. Based on the results of the analysis of the hypothesis test, it is obtained t count $(7,734)>$ sig $(0,000)$, so the regression coefficients $X$ and $Y$ tested are significant. So the results of the study show that reading interest has continuity with learning outcomes. It is obtained from the percentage of learning outcomes of Indonesian students of high grade students of SDN 1 Ciporang.

Keywords: reading interests, learning outcomes, indonesian language
\end{abstract}

\section{Abstrak}

Tujuan dari penelitian ini untuk mengetahui pengaruh minat baca terhadap hasil belajar siswa, Penelitian ini menggunakan pendekatan kuantitatif dengan metode survey. Populasi pada penelitian adalah seluruh siswa kelas tinggi yang berjumlah 197 siswa. Pengumpulan data yang digunakan berupa angket berskala Likert. Teknik analisis data menggunakan analisis regresi sederhana. Hasil penelitian menunjukkan adanya pengaruh yang positif dan signifikan minat baca terhadap hasil belajar bahasa Indonesia siswa kelas tinggi di SDN 1 Ciporang Kabupaten Kuningan. Hasil pengolahan data bahwa minat baca siswa menurut persepsi responden mencapai $43,66 \%$ termasuk kategori kriterium sedang dan hasil belajar siswa mencapai $62,95 \%$ termasuk kategori baik. Berdasarkan hasil analsis uji hipotesis diperoleh t hitung $(7,734)>$ sig $(0,000)$ maka koefisien regresi $X$ dan $Y$ yang diuji adalah signifikan. Maka hasil penelitian menunjukan bahwa minat baca memiliki kesinambungan dengan hasil belajar hal tersebut didapat dari hasil presentase hasil belajar siswa bahasa Indonesia siswa kelas tinggi SDN 1 Ciporang.

Kata Kunci : minat baca, hasil belajar, bahasa indonesia 


\section{PENDAHULUAN}

Mata pelajaran Bahasa Indonesia tercantum dalam struktur kurikulum 2013 untuk SD/MI dan SMP/MTs. Menurut Cahyani \& Rosmana (2013) bahwa pembelajaran Bahasa Indonesia di sekolah umumnya ditujukan agar para peserta didik mempunyai empat kompetensi dalam aspek berbahasa yaitu, menyimak atau mendengarkan, membaca, menulis dan berbicara. Demikian disebutkan oleh (Nurdiyanti \& Suryanto, 2010) bahwa tujuan pelaksanaan pembelajaran Bahasa Indonesia yang ada di SD adalah siswa dapat melakukan komunikasi dengan pelafalan yang jelas dan sesuai dengan kaidah yang berlaku di lingkungan masyarakat baik secara lisan maupun tulisan. Dengan harapan dapat berkomunikasi dengan lebih luwes dan juga dapat dipahami dengan mudah, serta mampu berbahasa Indonesia dengan baik dan benar sesuai kaidah bahasa yang belaku (Zubaidah et al., 2018).

Kegiatan membaca akan menjadi lebih efektif jika siswa memiliki minat baca yang tinggi, namun kenyataannya minat baca masyarakat Indonesia masih tergolong rendah. Hal ini terlihat dari Hasil survey PISA tahun 2016 yang dilansir dari Gerakan Literasi Sekolah Antoro (2017) mengemukakan bahwa Indonesia menduduki peringkat enam puluh empat dari tujuh puluh negara yang disurvei.

Berdasarkan hasil wawancara dan observasi terkait minat baca yang dilakukan di SD Negeri 1 Ciporang ditemukan permasalahan pada aspek kemampuan membaca yaitu minat membaca siswa kelas tinggi di SD tersebut masih rendah. Rendahnya minat membaca siswa ditunjukkan dengan siswa yang kurang tertarik mengunjungi perpustakaan untuk membaca maupun meminjam buku. Hal tersebut terlihat karena kurangnya fasilitas perpustakaan yang digunakan kurang layak sehingga mengakibatkan kurangnya minat baca siswa ke perpustakaan (Teguh, 2017). Dalam proses pembelajaran ketika siswa diminta untuk membaca buku saat pembelajaran Bahasa Indonesia berlangsung, terlihat beberapa siswa mengeluh karena teks yang dibaca terlalu panjang pada akhirnya siswa hanya membolak-balik halaman buku. Demikian ditemukan siswa lebih memilih berbicara dengan temannya daripada membaca. Hal ini disebabkan karena siswa kurang mengutamakan kegiatan membaca dalam kesehariannya, ketika memiliki waktu luang, ternyata siswa lebih memilih untuk bermain bersama teman-temannya (Firmansyah, 2018). Hal lain terlihat bahwa siswa juga belum memiliki inisiatif untuk membaca buku atas kemauannya sendiri. Biasanya, siswa baru membaca apabila diperintah oleh gurunya untuk membaca (Doman, 2010). Demikian pendapat Aprinawati (2018) bahwa sebagian besar kegiatan belajar adalah membaca. Suka atau tidak suka, artinya sebagai siswa diwajibkan untuk membaca buku. Bahasa Indonesia termasuk salah satu muatan yang dipelajari di Sekolah Dasar. Oleh karena itu, salah satu cara untuk mempelajari bahasa Indonesia dapat dilakukan dengan membaca.

Selanjutnya Triatma (2016) mengemukakan bahwa minat merupakan faktor yang mempengaruhi seseorang untuk membaca. Minat menjadi penting 
dalam membaca karena tanpa minat, membaca menjadi berat dan membosankan. Hasil penelitian yang dilakukan oleh Nurlaela et al., (2018) menyatakan jika hasil belajar yang diperoleh siswa setara dengan minat baca yang dimilikinya. Semakin tinggi minat baca pada diri seseorang semakin tinggi pula hasil belajar yang diterimanya.

Berdasarkan hasil nilai Ulangan Tengah Semester satu muatan pelajaran Bahasa Indonesia siswa tinggi yang meliputi kelas IV, V dan VI tahun ajaran 2018/2019 menunjukkan bahwa $76 \%$ dari seratus sembilan puluh tujuh siswa, nilainya belum mencapai Kriteria Ketuntasan Minimal $(\mathrm{KKM}=70)$. Salah satu penyebab rendahnya hasil belajar Bahasa Indonesia diduga karena rendahnya minat membaca siswa.

Hasil Penelitian yang dilakukan oleh Nurlaela et al., (2018) menunjukkan bahwa minat baca yang rendah menyebabkan hasil belajar siswa menjadi kurang optimal. Hal tersebut tidak lagi menherankan karena seiring dengan kemajuan teknologi kebiasaan siswa untuk membaca semakin berkurang. Umumnya siswa menjadi malas membaca dan lebih banyak menghabiskan waktunya untuk bermain game maupun mengakses media sosial. Selnajutnya penelitian lain yang dilakukan oleh Rahayu, (2015) menunjukkan bahwa rendahnya minat baca siswa berakibat pada rendahnya prestasi belajar siswa kelas V SD Kecamatan Kasihan Kabupaten Bantul.

Minat baca merupakan aktivitas yang dilakukan dengan penuh ketekunan dalam rangka membangun pola komunikasi dengan diri sendiri untuk menemukan makna tulisan dan menemukan informasi untuk mengembangkan intelektualitas yang dilakukan dengan penuh kesadaran dan perasaan senang yang timbul dari dalam dirinya (Tarigan, 2018). Selanjutnya Djamarah \& Zain (2013) menyatakan bahwa minat baca merupakan keinginan dan kemauan kuat untuk selalu membaca setiap kesempatan atau selalu mencari kesempatan untuk membaca.

Minat baca yang ada dalam diri seseorang tidak tumbuh begitu saja tanpa adanya faktor yang mempengaruhi. Selanjutnya Wahyuni (2015) menjelaskan bahwa faktor yang mempengaruhi minat membaca pada anak adalah karena faktor internal seperti intelegensi, usia, jenis kelamin, kemampuan membaca, sikap, serta kebutuhan psikologis. Adapun faktor eksternal yang mempengaruhi minat baca seperti belum tersedianya bahan bacaan yang sesuai, status sosial, ekonomi, kelompok etnis, pengaruh teman sebaya, orang tua, guru, televise, serta film.

Indikator minat baca menurut yaitu frekuensi dan kuantitas membaca serta kualitas sumber bacaan (Dalman, 2014). Sedangkan menurut Maharani et al., (2017) ada empat aspek yang dapat digunakan untuk mengetahui tingkat minat baca seseorang yaitu, 1) kesenangan membaca; 2) kesadaran akan manfaat membaca; 3) frekuensi membaca; dan 4) jumlah buku yang pernah dibaca.

Minat baca yang diharapakan ada pada peserta didik adalah keinginan yang begitu kuat disertai usaha yang intens dan beragam untuk membaca. Karena pada dasarnya, seseorang yang mempunyai ketertarikan untuk membaca yang kuat akan diwujudkannya dalam kesediaanya untuk memperoleh bahan untuk dibaca yang kemudian 
membacanya atas kesediannya sendiri atau dorongan dari pihak lain (Teguh, 2017). Dengan minat baca yang sudah tertaman pada diri siswa maka diharapkan akan meningkat pula hasil belajar pada pelajaran Bahasa Indonesia. Menurut Triatma, (2016) hasil belajar merupakan perubahan perilaku yang berupa pemahaman, keterampilan, dan sikap yang diperoleh siswa selama berlangsungnya proses belajar mengajar atau yang lazim disebut pembelajaran. Penelitian ini bertujuan untuk mengetahui pengaruh minat baca terhadap hasil belajar bahasa Indonesia siswa kelas tinggi SD Negeri 1 Ciporang.

\section{METODE}

Penelitian ini menggunakan penelitian kuantitatif. Menurut Nenty (2009) bahwa Penelitian kuantitatif berupaya untuk mengungkap kebenaran dan prinsip universal dalam bentuk hubungan antar variabel atau fenomena. Ciri dalam penelitian kuantitatif yaitu teknik analisis datanya menggunakan teknik kuantitatif (statistika) secara objektif (Creswell, 2010). Sedangkan jenis penelitian ini menggunakan metode survey. Menurut Sari et al., (2020) bahwa metode survey yakni sebuah merupakan suatu pemeriksaan atau penelitian secara komprehensif dipandang sebagai metode untuk menggambarkan secara kuantitatif aspek-aspek spesifik dari populasi tertentu sehingga pengumpulan datanya dilakukan kepada sekolompok orang yang hasilnya dapat digeneralisasi kembali ke dalam suatu populasi tertentu.

Subjek dalam penelitian ini adalah siswa kelas tinggi yang terdiri dari 6 rombel SDN 1 Ciporang yang jumlah 197 siswa. Instrumen yang digunakan dalam penelitian ini adalah data survey. Adapun surveynya dalam bentuk kuisione. Survey yang dibuat bertujuan untuk mengungkap minat baca siswa yang berpengaruh terhadap hasil belajar siswa jenis surveynya menggunakan skala likert. Menurut Sugiyono (2018) bahwa skala likert digunakan sebagai alat untuk mengukur sikap, pendapat, dan persepsi individu atau sekolompok orang terhadap fenomena sosial. Adapun tabel skala likert disajikan di bawah ini.

Tabel 1. Skala Likert

\begin{tabular}{cc}
\hline Kriteria Penilaian & Skala Penilaian \\
\hline Sangat Setuju & 5 \\
Setuju & 4 \\
Cukup/Netral & 3 \\
Tidak Setuju & 2 \\
Sangat Tidak Setuju & 1 \\
\hline
\end{tabular}

Sementara untuk teknik analisis data pada penelitian ini dilakukan dengan menghitung peolehan skor rata-rata hasil belajar siswa kemudian hasil perhitungan skor rata-rata di

lakukan uji regresi yang selanjutnya dianalisis dan disimpulkan.

Uraikan dengan jelas prosedur penelitian yang dilakukan. Metode yang dipilih agar disesuaikan dengan 
jenis penelitiannya. Sebagai contoh penelitian eksperimen, desain sampel serta prosedur pelaksanaan penelitian, pengambilan populasi dan

penelitian harus jelas.

\section{PEMBAHASAN}

Penelitian ini menggunakan instrumen skala yang disusun dalam bentuk kuesioner (angket) serta dokumentasi. Angket minat baca dibuat berdasarkan kisi-kisi yang telah disesuaikan dengan kajian pustaka. Instrumen tersebut kemudian diuji coba ke 25 responden untuk kemudian dihitung validitas dan reliabilitasnya. Instrumen berisi pernyataan positif dan pernyataan negatif dengan empat alternatif pilihan jawaban. Butir pernyataan tidak valid dinyatakan gugur dan tidak digunakan dalam penelitian.

Data tentang minat baca diperoleh melalui jawaban siswa pada skala minat baca yang diisi oleh 197 responden. Skor tertinggi yang didapat adalah 128 dan skor terendah adalah 53. Mean yang diperoleh sebesar 95,94. Standar deviasi yang diperoleh adalah 14,27. Berdasarkan data tersebut, minat baca baca dibedakan menjadi lima kategori menurut Azwar (2003) sebagai berikut.

Tabel 2. Klasifikasi Data Minat Baca

\begin{tabular}{|c|c|c|c|c|}
\hline No & Interval & Kategori & Frekuensi & Presentase \\
\hline 1 & $>118$ & Sangat tinggi & 24 & $12,18 \%$ \\
\hline 2 & $98-118$ & Tinggi & 62 & $31,48 \%$ \\
\hline 3 & $77-96$ & Sedang & 86 & $43,66 \%$ \\
\hline 4 & $56-76$ & Rendah & 19 & $9,64 \%$ \\
\hline 5 & $<56$ & Sangat Rendah & 6 & $3,04 \%$ \\
\hline \multicolumn{3}{|c|}{ Total } & 197 & $100 \%$ \\
\hline
\end{tabular}

Dari tabel 4 dapat disimpulkan kategori sedang. Untuk lebih jelasnya bahwa minat baca yang terdapat di dapat dilihat pada diagram di bawah SDN 1 Ciporang termasuk dalam ini.

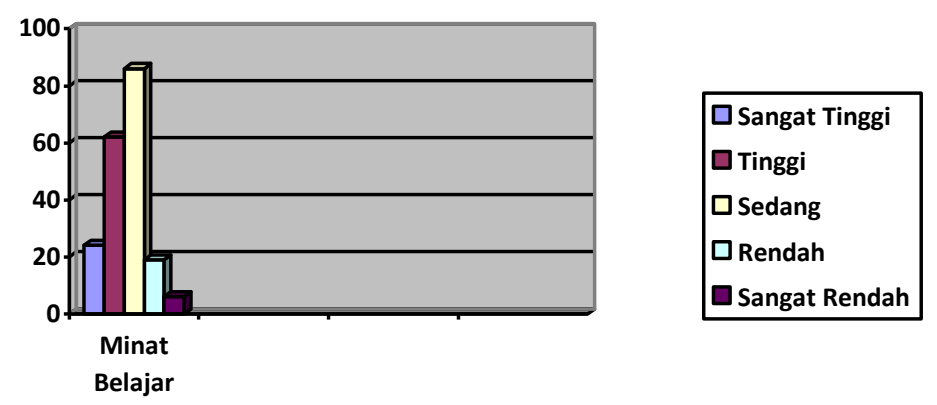

\section{Gambar 1. Diagram kategori minat baca}

Data hasil belajar bahasa dokumentasi nilai rapor bahasa Indonesia mencakup nilai kognitif Indonesia. Nilai tertinggi yang didapat siswa pada muatan bahasa Indonesia. adalah 90 dan nilai terendah adalah Hasil belajar siswa diperoleh melalui 65 . Berdasarkan data tersebut, minat 
baca dibedakan menjadi lima kategori sebagai berikut.

Tabel 3. Klasifikasi Data Hasil Siswa

\begin{tabular}{|c|c|c|c|c|}
\hline No & Interval & Kategori & Frekuensi & Presentase \\
\hline 1 & $80-100$ & Baik Sekali & 52 & $26,40 \%$ \\
\hline 2 & $66-79$ & Baik & 124 & $62,95 \%$ \\
\hline 3 & $56-65$ & Cukup & 21 & $10,65 \%$ \\
\hline 4 & $40-55$ & Kurang & 0 & $0 \%$ \\
\hline 5 & $30-39$ & Gagal & 0 & $0 \%$ \\
\hline \multicolumn{3}{|c|}{ Total } & 197 & $100 \%$ \\
\hline
\end{tabular}

Dari tabel 5 dapat disimpulkan jelasnya dapat dilihat pada diagram di bahwa hasil belajar bahasa Indonesia bawah ini.

siswa SDN 1 Ciporang termasuk dalam kategori Baik. Untuk lebih

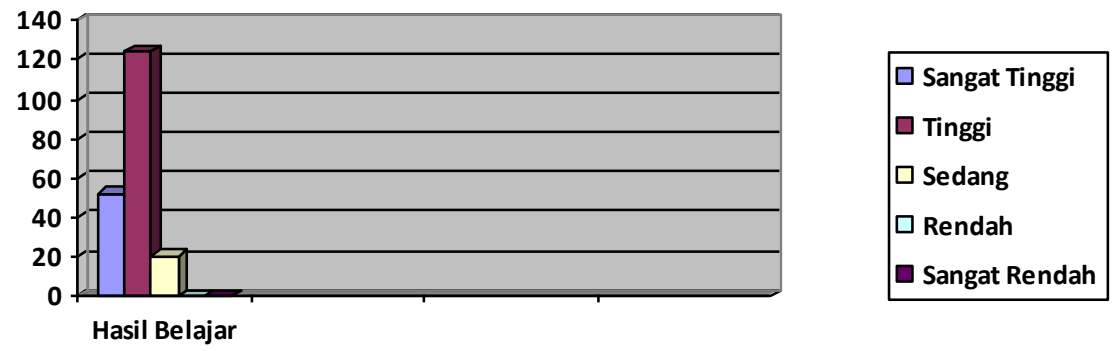

Gambar 2. Diagram Hasil Belajar Siswa

Pengujian

hipotesis menggunakan teknik analisis regresi linier sederhana. Hasil pengujian menunjukkan nilai signifikansi sebesar 0,024 (Regresi / Uji F) Nilai signifikasi sebesar $0,000<0,050$ hal ini menunjukkan bahwa minat membaca sangat signifikan terhadap hasil belajar. Hal tersebut menunjukkan hasil belajar dapat dipengaruhi oleh minat baca dan minat baca merupakan faktor dari luar diri siswa yang dapat menurunkan ataupun meningkatkan dalam belajar.

Berdasarkan analisis deskriptif diketahui bahwa minat baca berada pada kategori sangat rendah sebanyak 3,04\%, kategori rendah sebanyak 9,64\%, kategori sedang sebanyak 43,66\%, kategori tinggi sebanyak $31,48 \%$, dan kategori sangat tinggi sebanyak $12,18 \%$ sehingga dapat diketahui bahwa tingkat minat baca siswa berada dalam kategori sedang.

Begitu pula dengan variabel hasil belajar bahasa Indonesia siswa SDN 1 Ciporang berada pada kategori baik sekali berjumlah $26,40 \%$, siswa dalam kategori baik berjumlah $62,95 \%$, siswa dalam kategori cukup berjumlah $10,65 \%$, dan tidak ada siswa yang termasuk dalam kategori kurang ataupun gagal sehingga dapat diketahui bahwa tingkat hasil belajar bahasa Indonesia berada dalam kategori baik. Seperti yang sudah dikemukakan oleh Nuryanti (2019) yang menyatakan bahwa berkaitan dengan kegiatan belajar, minat tertentu dimungkinkan akan berpengaruh terhadap hasil belajar 
siswa Oleh karena itu, minat baca juga memiliki pengaruh terhadap hasil belajar bahasa Indonesia yang diperoleh siswa.

Kemudian uji prasayarat yang dilakukan yakni uji linieritas. Melalui perhitungan diketahui data yang dihasilkan dalam penelitian ini, kedua variabel memiliki keterikatan linier sebesar 7,734 yang lebih besar dari $0,05(7,734>0,05)$.

Berdasarkan hasil analisis regresi linier sederhana diperoleh $Y^{\prime}=$ $61,585+0,114 X$. Konstanta sebesar 61,585 artinya jika minat baca $(X)$ nilainya adalah nol (0), maka hasil belajar bahasa Indonesia (Y) nilainya positif 61,9585. Koefisien regresi $X$ sebesar 0,144 menyatakan bahwa setiap penambahan 1 nilai pada minat baca (X), maka nilai hasil belajar bahasa Indonesia mengalami kenaikan sebesar 0,144. Koefisien ini bernilai positif artinya terjadi hubungan positif antara minat baca dengan hasil belajar bahasa Indonesia, semakin tinggi minat baca siswa maka semakin tinggi hasil belajar bahasa Indonesia nya. Nilai Sig. pada uji regresi menunjukkan hasil 0,000 yakni lebih kecil dari 0,05 $(0,00<0,05)$ yang berarti bahwa pengaruh yang terjadi signifikan.

Dari uraian tersebut dapat dijelaskan bahwa minat baca memberikan kontribusi pada hasil belajar bahasa Indonesia siswa. Oleh karena itu, siswa yang memiliki minat baca yang tinggi akan memperoleh hasil belajar bahasa Indonesia yang tinggi pula, dan sebaliknya jika siswa memiliki minat baca yang rendah maka akan memperoleh hasil belajar bahasa Indonesia yang rendah pula (Andriani \& Rasto, 2019). Ini sesuai dengan pendapat Nurlaela et al., (2018) yang menyatakan bahwa berkaitan dengan kegiatan belajar, minat tertentu dimungkinkan akan berpengaruh terhadap hasil belajar siswa. Hal ini diperkuat oleh pendapat Triatma (2016) yang menyatakan bahwa minat memberikan sumbangan yang besar terhadap keberhasilan belajar peserta didik. Semakin sering seorang siswa membaca, maka pengetahuan dan wawasan yang dimilikinya akan semakin luas.

Dalam kehidupan sehari-hari, terutama kegiatan anak selama di rumah tentu yang paling bertanggung jawab atas perkembangan anak adalah orang tua, sehingga dalam kegiatan belajar sangatlah diperlukan adanya peran orangtua untuk memberi perhatian, bimbingan, pengawasan, pemberian motivasi atau dorongan dari orang tua, baik yang bersifat nampak maupun tidak nampak. Oleh karena itu keluarga juga mempunyai peranan besar dalam menimbulkan minat baca dalam diri siswa (Parmadani \& Latifah, 2016). Pengetahuan dan wawasan yang dimiliki siswa akan mendukung proses belajarnya. Siswa yang minat bacanya tinggi, pengetahuannya akan tinggi sehingga hasil belajarnya akan menjadi baik. Begitupun sebaliknya, jika minat baca rendah, maka pengetahuan yang dimiliki kurang sehingga akan berdampak pada hasil belajar siswa yang rendah (Dinar \& Maspuroh, 2019).

Hal ini terbukti dari hasil uji hipotesis yang menyatakan bahwa $\mathrm{HO}$ ditolak dan $\mathrm{Ha}$ diterima. $\mathrm{Ha}$ yang diterima dalam penelitian ini yaitu: ada pengaruh positif dan signifikan antara minat baca terhadap hasil belajar bahasa Indonesia siswa kelas tinggi SDN 1 Ciporang Kecamatan Kuningan Kabupaten Kuningan. 


\section{SIMPULAN}

Menyajikan pembahasan simpulan penelitian atau gagasan ilmiah, implikasi serta rekomendasi lebih jauh yang menjadi prospek kajian berikutnya.

Berdasarkan hasil pengujian dan analisis maka dapat diambil kesimpulan bahwa hasil belajar peserta didik kelas tinggi di SD Negeri 1 Ciporang berada pada kategori rendah dengan rata-rata nilai variabel sebesar 51,84. Selanjutnya minat baca siswa kelas tinggi di SD Negeri 1 Ciporang berada pada kategori sedang dengan rata-rata nilai variabel sebesar 85,96 dan termasuk kedalam kategori tinggi. Hal ini berarti minat baca siswa berpengaruh positif terhadap hasil belajar siswa, Artinya semakin tinggi Minat Baca peserta didik maka Hasil Belajar peserta didik akan semakin meningkat.

\section{DAFTAR PUSTAKA}

Andriani, R., \& Rasto, R. (2019). Motivasi belajar sebagai determinan hasil belajar siswa. Jurnal Pendidikan Manajemen Perkantoran, 4(1), 80. https://doi.org/10.17509/jpm.v4i1. 14958

Antoro, B. (2017). Gerakan Literasi Sekolah. Jakarta : Kemendikbud.

Aprinawati, I. (2018). Penggunaan Model Peta Pikiran (Mind Mapping) Untuk Mneingkatkan Pemahaman Membaca Wacana Siswa Sekolah Dasar. Jurnal Basicedu, 2(1), 140-147.

Azwar, S. (2003). Penyusunan Skala Psikologi. Yogyakarta: Pustaka Pelajar.

Cahyani, I., \& Rosmana, I. . (2013). Pendidikan Bahasa Indonesia. Bandung: UPI PRESS.

Creswell, J. W. (2010). Research Design: Pendekatan Kualitatif, Kuantitatif, dan Mixed. Pustaka Pelajar.

Dalman. (2014). Keterampilan Membaca. Jakarta: Raja Grafindo Persada.

Dinar, P. W., \& Maspuroh, U. (2019). Pengaruh Model Pembelajaran Dan Minat Baca Terhadap Hasil
Belajar Apresiasi Puisi. LITERASI, Jurnal IImiah Pend. Bahasa, Sastra Indonesia Dan Daerah, 9(1), 48-60.

Djamarah, S. B., \& Zain, A. (2013). Strategi belajar mengajar (Cet.5). Jakarta: Rineka Cipta.

Doman, G. (2010). Meningkatkan Minat Membaca Siswa Sekolah Dasar Dengan Metode Glenn Doman Berbasis Multimedia. Jurnal Penelitian Pendidikan Unnes, $27(1), \quad 124265$. https://doi.org/10.15294/jpp.v27i1. 194

Firmansyah, D. (2018). Analysis of Language Skills in Primary School Children (Study Development of Child Psychology of Language). PrimaryEdu Journal of Primary Education, 2(1), 35. https://doi.org/10.22460/pej.v1i1.6 68

Maharani, O. D., Laksono, K., \& Sukartiningsih, W. (2017). Minat Baca Anak-anak di Kampoeng Baca Kabupaten Jember. Jurnal Review Pendidikan Dasar: Jurnal Kajian Pendidikan Dan Hasil Penelitian, 3(1), 320-328. 
Nenty, H. J. (2009). Writing a Quantitative Research Thesis. International Journal of Educational Sciences, 1(1), 1932.

https://doi.org/10.1080/09751122. 2009.11889972

Nurdiyanti, E., \& Suryanto, E. (2010). Pembelajaran Literasi Mata Pelajaran Bahasa Indonesia pada Siswa Kelas V Sekolah Dasar. Paedagogia, 13(2), 115-128.

Nurlaela, L., Samani, M., Asto, I. G. P., \& Wibawa, S. C. (2018). The effect of thematic learning model, learning style, and reading ability on the students' learning outcomes. IOP Conference Series: Materials Science and Engineering, 296(1). https://doi.org/10.1088/1757899X/296/1/012039

Nuryanti, R. (2019). Pengaruh Kualitas Pelaksanaan Gerakan Literasi dan Minat Baca Terhadap Hasil Belajar Berbicara Siswa SD Negeri Segugus Taman, Kota Madiun. Linguista: Jurnal IImiah Bahasa, Sastra, Dan Pembelajarannya, 3(2), 105. https://doi.org/10.25273/linguista. v3i2.5733

Parmadani, T. S., \& Latifah, L. (2016). Pengaruh Minat Baca, Sumber Belajar dan Lingkungan Teman Sebaya Terhadap Prestasi Belajar Ekonomi. Economics Education Analysis Journal, 4(2), 496-508.

https://doaj.org/article/28ab3f75d 13d4201a37d84066c039a8f

Rahayu, G. S. (2015). Pengaruh Minat Baca Terhadap Prestasi Belajar Ips Siswa Kelas V Sd Se-Gugus li Kasihan Bantul Tahun Ajaran 2014 / 2015. Jurnal Penididkan
Guru Sekolah Dasar.

Sari, M. Z., Fitriyani, Y., \& Amalia, D. (2020). Analisis Bahan Ajar Keragaman Suku Bangsa dan Budaya dalam Implementasi Karakter Toleransi di Sekolah Dasar. Jurnal Kependidikan: Jurnal Hasil Pendidikan Dan Kajian Kepustakaan Di Bidang Pendidikan Pengajaran Dan Pembelajaran, 6(3), 382-396. https://doi.org/https://doi.org/10.3 3394/jk.v6i3.2824

Sugiyono. (2018). Metode Penelitian Kuantitatif, Kualitatif dan $R \& D$. Bandung: Alfabeta.

Tarigan, N. T. (2018). Pengembangan Buku Cerita Bergambar Untuk Meningkatkan Minat Baca Siswa Kelas Iv Sekolah Dasar. Jurnal Curere, 2(2), 2597-9515.

Teguh, M. (2017). Gerakan Literasi Sekolah Dasar. Prosiding Seminar Nasional, 2(1), 18-26.

Triatma, I. . (2016). Minat Baca Pada Siswa Kelas VI Sekolah Dasar Negeri Delegan. E-Jurnal Prodi Teknologi Pendidikan, 5(6), 166178.

Wahyuni, S. (2015). Menumbuhkembangkan Minat Baca Menuju Masyarakat Literat. Diksi, 17(1), 179-189. https://doi.org/10.21831/diksi.v17i 1.6580

Zubaidah, S., Corebima, A. D., Mahanal, S., \& Mistianah. (2018). Revealing the relationship between reading interest and critical thinking skills through remap Gl and remap jigsaw. International Journal of Instruction, 11(2), 41-56. https://doi.org/10.12973/iji.2018.1 $124 \mathrm{a}$ 